\title{
Aktivitas dan Hasil Belajar Siswa pada Pembelajaran Matematika Menurut Teori Belajar Jerome Bruner untuk Materi Keliling dan Luas Lingkaran di Kelas VIII
}

\author{
Winda Agustina $^{1 *}$, Zahra Chairani ${ }^{2}$, Norhabibah ${ }^{3}$ \\ 1,2,3 STKIP PGRI Banjarmasin \\ winda.agustina@stkipbjm.ac.id
}

\begin{abstract}
The purpose of this research want know how the activities and learning outcomes of students VIII MTs Al Falah MaheTabalong Regency 2018/2019 academic year by applying Jerome Bruner's learning theory on learning about the circumference and area of circle. This research is a quantitative descriptive study consisting of three meetings, two meetings for learning acitivites and one meeting for evaluation test. Data collection technique using observation and test. Data analysis technique used average dan percentage. The resultof the research show that by applying Jerome Bruner's learning theory in learning activities students were in active qualifications and student learning outcomes were in good qualification.
\end{abstract}

Keywords: Jerome Bruner's learning theory, circle

Abstrak: Tujuan penelitian untuk mengetahui bagaimana aktivitas dan hasil belajar siswa kelas VIII MTs Al Falah Mahe Kabupaten Tabalong Tahun Pelajaran 2018/2019 dengan menerapkan teori belajar Jerome Bruner pada pembelajaran tentang keliling dan luas lingkaran. Penelitian ini adalah penelitian deskriptif kuantitatif yang terdiri dari tiga kali pertemuan, dua kali pertemuan untuk kegiatan pembelajaran dan satu pertemuan untuk pelaksanaan tes evaluasi. Teknik pengumpulan data dalam penelitian ini menggunakan observasi dan tes hasil belajar. Teknik analisis data dengan menggunakan hitung rata-rata dan persentase. Hasil penelitian menunjukkan bahwa dengan menerapkan teori belajar Jerome Bruner dalam pembelajaran, aktivitas belajar siswa berada pada kualifikasi aktif dan hasil belajar siswa berada pada kualifikasi baik.

Kata kunci: teori belajar Jerome Bruner, lingkaran

\section{PENDAHULUAN}

Pendidikan hendaknya memberikan siswa pengalaman belajar secara aktif di dalam pembelajaran. Namun, situasi yang sering terjadi di kelas adalah guru dalam kegiatan pembelajaran memberikan konsep ataupun rumus matematika secara langsung kepada siswanya sehingga siswa tidak terbiasa untuk menemukan sendiri konsep matematika. Situasi ini juga terjadi di MTs Al Falah Mahe kelas VIII, pada saat proses pembelajaran materi lingkaran subbab keliling dan luas lingkaran, guru mengajar dengan memberikan rumus secara langsung kepada siswa tanpa memberikan kesempatan kepada siswa untuk menemukan sendiri konsep dari keliling dan luas lingkaran sehingga materi pelajaran menjadi mudah dilupakan oleh siswa. Di samping itu, matematika yang bersifat abstrak membuat siswa sulit untuk memahami materi secara langsung sehingga diperlukan tahapan demi tahapan untuk membangun pemahaman siswa, misalnya dimulai dengan memberikan benda konkrit kepada siswa, lalu penggunaan gambar atau model sampai kepada penggunaan simbol-simbol abstrak.Untuk mengatasi permasalahan tersebut, guru hendaknya menerapkan teori belajar yang tepat agar dapat memberikan kemudahan siswa untuk menerima dan memahami konsep materi yang diajarkan.

Salah satu teori belajar yang dapat membantu mengatasi masalah tersebut yaitu teori belajar dari Jerome Bruner. Menurut Bruner dalam Smith (2009: 123) ada tiga tahapan dalam 
teori Bruner tentang perkembangan intelektual, yaitu (1) tahap enaktif, dimana seseorang belajar tentang dunia melalui aksi-aksi terhadap obyek; (2) tahap ikonik dimana pembelajaran terjadi melalui penggunaan model-model dan gambar-gambar dan tahap simbolik yang menggambarkan kapasitas berpikir dalam istilah-istilah yang abstrak.

Belajar pada hakikatnya adalah proses interaksi terhadap semua situasi yang ada di sekitar individu siswa. Belajar dapat dipandang sebagai proses yang diarahkan kepada tujuan dan proses berbuat melalui berbagai pengalaman. Belajar juga merupakan proses melihat, mengamati, menalar, mencobakan, mengomunikasikan, dan memahamisesuatu (Rusman, 2017: 1). Menurut Slameto (2010: 54), faktor-faktor yang mempengaruhi belajar banyak jenisnya, dapat digolongkan menjadi dua, yaitu faktor intern dan faktor ekstern. Faktor intern adalah faktor yang ada dalam diri individu yang sedang belajar, sedangkan faktor ekstern adalah faktor yang di luar diri individu. Ide Bruner dalam Smith (2009: 122), yang menganjurkan penemuan pembelajaran, kemungkinan mempunyai penerimaan yang lebih besar, setidaknya di sekolah, daripada ide yang dilontarkan oleh Ausubel atau Gagne. Pada 1966, Bruner menulis Toward of Instruction, yang di dalamnya dia menjelaskan bagaimana ide-idenya mungkin diterjemahkan ke dalam praktik di ruang kelas.

Bruner menyarankan agar para siswa hendaknya berpartisipasi secara aktif mempelajari konsep-konsep dan prinsip-prinsip pada materi pelajaran, agar mereka memperoleh berbagai pengalaman, dan melakukan berbagai eksperimen yang memungkinkan mereka untuk menemukan prinsip-prinsip itu sendiri (Trianto, 2010: 38). Sedangkan dalam Smith (2009: 123), Bruner berargumen bahwa kita harusnya mengajarkan "struktur subjek-subjek". Dia menganjurkan pendahuluan bagi proses nyata dari sebuah disiplin khusus terhadap siswa.

Smith (2009: 123) mengemukakan tiga tahapan dalam teori Bruner tentang perkembangan intelektual adalah sebagai berikut.

1) Enactive, di mana seseorang belajar tentang dunia melalui aksi-aksi terhadap obyek,

2) Iconic, di mana pembelajaran terjadi melalui penggunaan model-model dan gambargambar.

3) Symbolic, yang menggambarkan kapasitas berpikir dalam istilah-istilah yang abstrak.

Sekolah merupakan salah satu pusat kegiatan siswa belajar, berbagai jenis aktivitas dapat dilakukan oleh siswa di sekolah. Menurut Paul B. Diedrich (dalam Hamalik, 2014: 90), berbagai aktivitas siswa dapat digolongkan menjadi aktivitas visual, lisan, menulis, mendengarkan, menggambar, metrik, mental, dan emosional.

Pembelajaran kooperatif adalah konsep yang lebih luas meliputi semua jenis kerja kelompok termasuk bentuk-bentuk yang lebih dipimpin oleh guru atau diarahkan oleh guru. Secara umum pembelajaran kooperatif dianggap lebih diarahkan oleh guru, di mana guru menetapkan tugas dan pertanyaan-pertanyaan serta menyediakan bahan-bahan dan informasi yang dirancang untuk membantu peserta didik menyelesaikan masalah yang dimaksud. Guru biasanya menetapkan ujian tertentu pada akhir tugas (Suprijono, 2009: 73). Menurut Sudjana hasil belajar merupakan suatu akibat dari proses belajar dengan menggunakan alat pengukuran, yaitu berupa tes yang disusun secara terencana. Sedangkan Nasution berpendapat bahwa hasil belajar adalah suatu perubahan pada individu yang belajar, tidak hanya mengenai pengetahuan, tetapi juga membentuk kecakapan dan penghayatan dalam diri pribadi individu yang belajar (Iskandar, 2012: 128).

Penelitian sebelumnya terkait teori Bruner oleh Lestari (2014) yang berjudul "Penerapan Teori Jerome Bruner untuk Meningkatkan Hasil Belajar Siswa pada Pembelajaran Simetri Lipat 
di Kelas IV SDN 02 Makmur Jaya Kabupaten Mamuju Utara", hasilnya menunjukkan bahwa terdapat peningkatan hasil belajar dan aktivitas siswa. Selain itu, hasil penelitian serupa oleh Del'an, Jamiah, \& Bistari (2013) menunjukkan pada pembelajaran menggunakan teori Bruner terjadi peningkatan aktivitas dan hasil belajar siswa.

Adapun tujuan dari penelitian ini adalah untuk: (1) mengetahui aktivitas siswa kelas VIII MTs Al Falah Mahe Kabupaten Tabalong Tahun Pelajaran 2018/2019 pada pembelajaran matematika dengan menerapkan Teori Belajar Jerome Bruner, dan (2) mengetahui hasil belajar siswa kelas VIII MTs Al Falah Mahe Kabupaten Tabalong Tahun Pelajaran 2018/2019 dengan menerapkan Teori Belajar Jerome Bruner.

\section{METODE}

Penelitian ini dilaksanakan di MTs Al Falah Mahe Kabupaten Tabalong selama 2 minggu pada semester genapTahun Pelajaran 2018/2019. Jenispenelitian yang digunakan adalah kuantitatif. Metode penelitian yang digunakan adalah metode deskriptif. Dalam melakukan penelitian ini menggunakan teknik pengumpulan data yaitu:

\section{Instrumen Pengumpulan Data Aktivitas Siswa}

Aktivitas siswa diamati menggunakan lembar observasi untuk mengukur aktivitas belajar siswa selama proses pembelajaran dengan menerapkan teori belajar Jerome Bruner. Lembar observasi aktivitas siswa yang di dalamnya terdapat 8 aspek kegiatan yang akan dinilai dan diamati oleh observer. Hasil penilaian yang diperoleh berbentuk skor 0 dan 1 .

\section{Instrumen Pengumpulan Hasil Belajar Siswa}

Data hasil belajar siswa diperoleh dari tes hasil belajar yang berisi 3 soal berbentuk uraian. Tes digunakan untuk menguji pemahaman siswa terhadap kegiatan pembelajaran yang sudah dilakukan. Sebelum digunakan tes sudah divalidasi oleh 1 orang dosen program studi pendidikan matematika dan 2 orang guru matematika di sekolah tempat penelitian.

\section{Analisis Data Aktivitas Siswa}

Perhitungan aktivitas siswa dengan menggunakan skor 0 atau 1 . Skor 1 untuk aktivitas yang dikerjakan, sedangkan skor 0 untuk aktivitas yang tidak dikerjakan. Hasil pengamatan observer digunakan untuk mengetahui aktivitas siswa dengan penerapan teori Bruner pada materi keliling dan luas lingkaran. Untuk mengukur aktivitas siswa tersebut digunakan teknik analisis persentase dari Sudijono (2014: 43), yang dihitung dengan rumus berikut.

Keterangan:

$$
\mathrm{P}=\frac{f}{N} \times 100 \%
$$

$\mathrm{P}=$ Angka Persentase

$f=$ Frekuensi yang sedang dicari persentasenya

$\mathrm{N}$ = Jumlah frekuensi/banyaknya individu (Sudijono, 2014: 43)

\section{Analisis Data Hasil belajar}

Guru memeriksa hasil jawaban siswa dan memberikan skor sesuai dengan pedoman penskoran yang telah ada, dimana setiap langkah jawaban siswa yang benar diberi skor 1 dan jika salah maka skornya 0 . Perhitungan nilai akhir dari hasil belajar menggunakan rumus sebagai berikut.

$$
\text { Nilai Akhir }=\mathrm{NA}=\frac{\text { jumla } h \text { skor yang diperole } h}{\text { skor } \text { maksimal }} \times 100
$$


Sedangkan untuk menghitung rata-rata hasil belajar siswa menggunakan rumus:

$$
\mathrm{M} x=\frac{\Sigma x}{N}
$$

Keterangan:

$$
\begin{aligned}
& \mathrm{M} x=\text { Mean yang dicari } \\
& \Sigma x=\text { Jumlah nilai siswa } \\
& \mathrm{N}=\text { Banyaknya individu (Adaptasi dari Sudijono, 2014:81) }
\end{aligned}
$$

\section{HASIL DAN PEMBAHASAN}

\begin{tabular}{|c|c|c|c|c|}
\hline \multirow[t]{2}{*}{ Aspek Aktivitas } & \multicolumn{2}{|c|}{$\begin{array}{c}\text { Persentase } \\
\text { Pertemuan ke- }\end{array}$} & \multirow{2}{*}{$\begin{array}{l}\text { Rata-rata } \\
\text { Persentase }\end{array}$} & \multirow{2}{*}{$\begin{array}{c}\text { Kualifikasi } \\
\text { Aktivitas }\end{array}$} \\
\hline & 1 & 2 & & \\
\hline $\begin{array}{l}\text { Melakukan percobaan dengan } \\
\text { benda nyata. }\end{array}$ & $59,1 \%$ & $77,3 \%$ & $68,2 \%$ & Aktif \\
\hline $\begin{array}{l}\text { Mengemukakan fakta hasil } \\
\text { pengukuran. }\end{array}$ & $54,5 \%$ & $63,6 \%$ & $59,1 \%$ & Cukup Aktif \\
\hline $\begin{array}{l}\text { Membuat gambar berdasarkan } \\
\text { benda nyata }\end{array}$ & $50 \%$ & $63,6 \%$ & $56,8 \%$ & Cukup Aktif \\
\hline $\begin{array}{l}\text { Mengamati gambar yang sudah } \\
\text { dibuat. }\end{array}$ & $77,3 \%$ & $81,8 \%$ & $79,5 \%$ & Aktif \\
\hline Berdiskusi dengan kelompok & $81,8 \%$ & $86,4 \%$ & $84,1 \%$ & Sangat Aktif \\
\hline $\begin{array}{l}\text { Menyelesaikan soal yang diberikan } \\
\text { guru. }\end{array}$ & $86,4 \%$ & $86,4 \%$ & $81,8 \%$ & Sangat Aktif \\
\hline Mempresentasikan hasil diskusi & $63,6 \%$ & $77,3 \%$ & $70,4 \%$ & Aktif \\
\hline $\begin{array}{l}\text { Menyimpulkan materi yang telah } \\
\text { dipelajari. }\end{array}$ & $54,5 \%$ & $59,1 \%$ & $56,8 \%$ & Cukup Aktif \\
\hline $\begin{array}{c}\text { Jumlah } \\
\text { Rata-rata } \\
\end{array}$ & $\begin{array}{l}518,2 \% \\
64,7 \% \\
\end{array}$ & $\begin{array}{l}595,4 \% \\
\mathbf{7 4 , 4 \%} \\
\end{array}$ & $\begin{array}{l}556,8 \% \\
\mathbf{6 9 , 6 \%} \\
\end{array}$ & Aktif \\
\hline
\end{tabular}

Hasil analisis data aktivitas belajar siswa selama kegiatan pembelajaran pada pertemuan pertama dan kedua dapat dilihat pada tabel berikut.

Tabel 1. Hasil Analisis Aktivitas Siswa Secara Klasikal

\section{Hasil Belajar Siswa}

Hasil belajar diperoleh melalui tes evaluasi, setelah semua lembar jawaban terkumpul maka dilakukan pengukuran atau analisis data. Hasil belajar siswa dapat dilihat pada Tabel 2 berikut ini.

Tabel 2. Kualifikasi Hasil Belajar Siswa

\begin{tabular}{cccc}
\hline Skor & Frekuensi & Persentase & $\begin{array}{c}\text { Kualifikasi } \\
\text { Hasil Belajar }\end{array}$ \\
\hline $100-89$ & 13 & $60 \%$ & Sangat Baik \\
$88-77$ & 6 & $27 \%$ & Baik \\
$76-65$ & 2 & $9 \%$ & Cukup \\
$<65$ & 1 & $4 \%$ & Kurang \\
Jumlah & 22 & $100 \%$ & - \\
Rata-rata & \multicolumn{2}{c}{$\mathbf{8 6 , 3 6}$} & Baik \\
\hline
\end{tabular}

Berdasarkan Tabel Kualifikasi Hasil Belajar dapat dilihat rata-rata hasil belajar siswa setelah mengikuti kegiatan pembelajaran dengan menerapkan Teori Belajar Jerome Bruner yaitu sebesar 86,36 dan tergolong pada kualifikasi baik. Dari daftar 
tersebut dapat diketahui bahwa banyaknya siswa yang mengikuti tes ada 22 orang. Sebagian besar hasil belajar siswa berada pada kualifikasi sangat baik dan baik, namun ada beberapa orang siswa yang hasil belajarnya berada pada kualifikasi cukup dan kurang. Jumlah siswa yang berada pada kualifikasi cukup ada 2 orang dan yang berada pada kualifikasi kurang ada satu orang.

Berdasarkan Kriteria Ketuntasan Minimal (KKM) yang telah ditentukan oleh pihak sekolah yaitu MTs Al Falah Mahe, siswa dinyatakan tuntas apabila memperoleh nilai minimal 65 pada tes. Dari analisis data diketahui bahwa dari segi individual, siswa sudah mencapai ketuntasan dengan rata-rata hasil belajar yaitu 86,36 yang tergolong pada kualifikasi baik, meskipun masih ada siswa yang nilainya belum mencapai KKM yang telah ditetapkan. Sedangkan dari segi klasikal siswa sudah dapat dikategorikan tuntas karena 95,45\% atau 21 siswa di kelas sudah mencapai nilai $\geq 65$. Grafik kualifikasi hasil belajar siswa dapat dilihat pada Gambar 1 berikut ini.

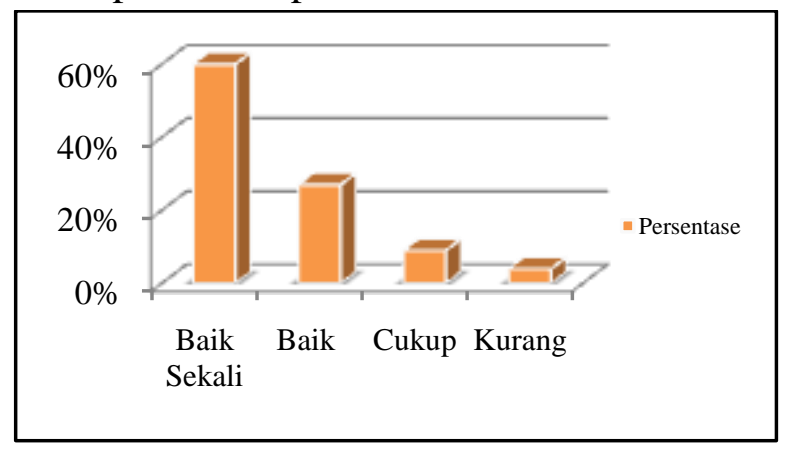

Gambar 1. Grafik Kualifikasi Hasil Belajar Siswa

\section{Pembahasan}

Aktivitas belajar siswa dalam penelitian ini diperoleh dari lembar observasi yang diisi langsung oleh dua orang observer pada saat peneliti melakukan kegiatan pembelajaran dengan menerapkan Teori Belajar Jerome Bruner sebanyak dua kali pertemuan. Berdasarkan hasil observasi pada pertemuan pertama dan kedua pada Tabel 1 diketahui bahwa rata-rata aktivitas siswa berada pada kualifikasi aktif, hal ini sesuai dengan pendapat Riduwan (2013: 89) yang menyatakan bahwa rentang persentase keaktifan siswa $61 \%<X \leq 80 \%$ termasuk dalam kategori aktif. Secara umum, aspek aktivitas siswa telah mengalami peningkatan, jika dibandingkan dari pertemuan pertama ke pertemuan kedua.

Kualifikasi aktivitas siswa dalam kategori aktif karena dengan menerapkan Teori Belajar Jerome Bruner dalam pembelajaran siswa melakukan percobaan maupun eksperimen dengan benda nyata secara langsung yang memungkinkan siswa terlibat secara aktif untuk menemukan suatu konsep dalam pembelajaran serta memperoleh pengalaman. Pembelajaran dengan menerapkan Teori Belajar Jerome Bruner dilakukan secara bertahap sehingga siswa juga dapat memahami materi secara bertahap sebelum mengambil kesimpulan dari pembelajaran yang telah dilakukan. Tahapan pembelajaran dalam Teori Belajar Jerome Bruner ada 3, yaitu enaktif, ikonik dan simbolik. Hal ini 
senada dengan pendapat yang dikemukakan oleh Smith (2009: 123) bahwa tiga tahapan dalam Teori Belajar Jerome Bruner tentang perkembangan intelektual.

Pada pembelajaran dengan menerapkan Teori Belajar Jerome Bruner siswa dibimbing untuk menemukan sendiri rumus keliling dan luas lingkaran dengan melakukan percobaan dengan benda nyata secara berkelompok, dalam satu kelompok terdiri dari 4 dan 5 orang siswa. Pertama-tama siswa bersama kelompoknya melakukan pengukuran pada benda, kemudian membuat gambar dari benda tersebut, setelah itu siswa berdiskusi dengan kelompoknya masing-masing sehingga siswa dapat menemukan konsep dari pembelajaran. Melalui diskusi siswa dapat belajar melalui proses interaksi dengan siswa lainnya maupun interaksi dengan guru. Ini sesuai dengan pendapat Rusman (2017: 1) yang mengatakan bahwa belajar merupakan suatu proses interaksi terhadap semua situasi yang ada di sekitar individu siswa, termasuk siswa lainnya dan guru.

Pembelajaran matematika dengan menerapkan Teori Belajar Jerome Bruner dalam pembelajaran membuat siswa berminat dan antusias siswa selama mengikuti pembelajaran serta membuat siswa terlibat aktif dalam pembelajaran. Hal ini dikarenakan pembelajaran dilakukan secara bertahap dengan cara melakukan eksperimen langsung terhadap benda nyata. Siswa menjadi lebih mudah memahami dan mengingat materi pembelajaran berdasarkan pengalamannya sebab proses belajar dilakukan guru secara bertahap dan siswa ikut terlibat aktif di dalamnya. Ini akan berdampak pada hasil belajar yang diperoleh siswa.

\section{SIMPULAN DAN SARAN \\ Simpulan}

Berdasarkan hasil penelitian yang telah diuraikan sebelumnya menunjukkan bahwa pembelajaran yang telah dilaksanakan dengan menerapkan teori belajar Jerome Bruner pada materi keliling dan luas lingkaran pada siswa kelas VIII MTs Al Falah Mahe Kabupaten Tabalong Tahun Pelajaran 2018/2019 membuktikan bahwa aktivitas siswa dalam kualifikasi aktif dan hasil belajar siswa dalam kualifikasi baik.

\section{Saran}

Berdasarkan hasil penelitian, pembahasan dan kesimpulan yang diuraikan pada penelitian penerapan TeoriBelajar Jerome Bruner dalam pembelajaran yang telah dilakukan, peneliti memberikan masukan atau saran yang perlu dipertimbangkan oleh berbagai pihak berkaitan dengan penerapan Teori Belajar Jerome Bruner dalam pembelajaran, sebagai berikut.

\section{Bagi Guru}

Agar kegiatan belajar menjadi menyenangkan serta efektif juga melibatkan siswa secara aktif selama kegiatan pembelajaran guru dapat menerapkan Teori Belajar Jerome Bruner tetapi hanya dapat digunakan pada materi pelajaran tertentu saja.

\section{Bagi Siswa}


Dengan diterapkannya Teori Belajar Jerome Bruner dalam pembelajaran, siswa diharapkan menjadi lebih mudah memahami materi pelajaran karena disampaikan oleh guru secara bertahap.

\section{Bagi Peneliti Lain}

Dapat melakukan penelitian lebih lanjut mengenai teori-teori belajar lain yang dapat digunakan dalam pembelajaran.

\section{DAFTAR PUSTAKA}

Del'an, Jamiah, Y., \& Bistari. (2013). Peningkatan Aktivitas Belajar Siswa Kelas VII SMP pada Bilangan Pecahan dengan Teori Bruner. Jurnal Pendidikan dan Pembelajaran Khatulistiwa, 2(12), 1-15.

Hamalik, Oemar. (2008). Kurikulum dan Pembelajaran. Jakarta: Bumi Aksara.

Iskandar. (2012). Penelitian Tindakan Kelas. Jakarta Selatan: Referensi (GP Press Group).

Lestari, Dewi. (2015). Penerapan Teori Jerome Bruner untuk Meningkatkan Hasil Belajar Siswa pada Pembelajaran Simetri Lipat di Kelas IV SDN 02 Makmur Jaya Kabupaten Mamuju Utara. Jurnal Kreatif Tadulako Online, 3(2), 129-141.

Riduwan. (2015). Belajar Mudah Penelitian. Bandung: CV. Alfabeta.

Rusman. (2017). Belajar \& Pembelajaran: Berorientasi Standar Proses Pendidikan. Jakarta: Kencana.

Sari, Herlyani N. (2015). Penerapan Teori Jerome Bruner Pada Materi Segiempat Di Kelas VII SMP Anggrek Banjarmasin Tahun Pelajaran 2014-2015. Skripsi. Skripsi tidak diterbitkan. Banjarmasin: STKIP PGRI Banjarmasin.

Slameto. (2010). Belajar dan Faktor-faktor yang Mempengaruhinya. Jakarta: PT. Raja Grafindo Persada.

Smith, Mark K., dkk. (2009). Teori Pembelajaran dan Pengajaran: Mengukur Kesuksesan Anda dalam Proses Belajar Mengajar Bersama Psikolog Pendidikan Dunia. Yogyakarta: Mirza Media Pustaka.

Sudijono, Anas. (2014). Pengantar Statistik Pendidikan. Jakarta: PT. Raja Grafindo Persada.

Suprijono, Agus. (2009). Cooperatif Learning Teori dan Aplikasi PAIKEM. Yogyakarta: Pustaka Belajar.

Trianto. (2010). Mendesain Model Pembelajaran Inovatif-Progresif: Konsep Landasan, dan Implemetasinya Pada Kurikulum Tingkat Satuan Pendidikan (KTSP). Jakarta: Kencana. 